\title{
Lexis
}

Journal in English Lexicology

11 | 2018

Lexis in Languages for Specific Purposes (LSP)

\section{From accouchement to agony: a lexicological analysis of words of French origin in the modern English language of medicine}

\section{Pascaline Faure}

\section{(2) OpenEdition \\ Journals}

Electronic version

URL: http://journals.openedition.org/lexis/1171

DOI: $10.4000 /$ lexis. 1171

ISSN: 1951-6215

Publisher

Université Jean Moulin - Lyon 3

\section{Electronic reference}

Pascaline Faure, «From accouchement to agony: a lexicological analysis of words of French origin in the modern English language of medicine », Lexis [Online], 11 | 2018, Online since 30 April 2018, connection on 30 April 2019. URL : http://journals.openedition.org/lexis/1171 ; DOI : 10.4000/ lexis. 1171

This text was automatically generated on 30 April 2019.

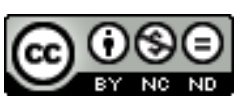

Lexis is licensed under a Creative Commons Attribution-NonCommercial-NoDerivatives 4.0 International License. 


\title{
From accouchement to agony ${ }^{1}:$ a lexicological analysis of words of French origin in the modern English language of medicine
}

\author{
Pascaline Faure
}

The author would like to express her gratitude to the anonymous Lexis reviewers of this article for their constructive comments and additional insights.

\section{Introduction}

1 Most of the papers and books that examine the European languages of medicine have focused on their anglicisation, be it French (Hamburger [1982], Faure [2010, 2012]), Spanish (Gutiérrez [1997], Navarro [1992], Ballesteros [2003], Alcaraz [2009]), Italian (Sartori [2013]), German (Fortuine [2001], Baethge [2008]), Hungarian (Keresztes [2013]), or Croatian (Dobrić [2013]). Although to a lesser extent, the opposite phenomenon - i.e. the influence of foreign languages on the English lexicon has also been widely examined, especially that of French (Prins [1952], Chirol [1973], Otman [1989], Chira [2000], Schultz [2012]). The fields that are usually mentioned as having been enriched by borrowings from French are diplomacy, cooking, military, love, fashion, tourism and arts, but very rarely medicine, although medical English owes a lot to French (Fortuine [2001: 211]). This might be explained by the fact that the pre-eminence of American English in the modern language of medicine is largely accepted (Wulff [2004]). Yet, medical research has not always been the privilege of the Americans and, before World War I, the French happened to dominate Western medicine (Sournia [1997], Dachez [2012]), influencing European medical languages. The present study is the first to examine the bulk of French loanwords in modern medical English.

2 Although $80.3 \%$ of the words used in the modern English language of medicine are derived from Latin and Greek (Butler cited by Taylor [2017: 3]), their immediate ancestor 
is often Old French via Anglo-Norman, which we examine in the second section of this paper. If in Medieval times, France was pre-eminent in the field of medicine, its greatest contributions occurred at the end of the $18^{\text {th }}$ century with the French Revolution and throughout the $19^{\text {th }}$ century, a time period to which our third section is devoted. The language of medicine is closely linked to the anatomists, physicians and surgeons that have been pioneers in the medical sciences. Therefore, French eponyms occupy a prominent place in the modern English medical terminology and are the subject of our fourth section.

\section{Materials and methods}

3 Despite the great number of definitions for specialised languages (SLs) over the years, we retained one which we think accounts for their complexity, namely that proposed by Van der Yeught [2016]. A specialised language (e.g. the medical language) is constructed around its community's intentionality (e.g. curing the sick), and conversely the community (e.g. healthcare professionals) constructs itself around its specialised language (e.g. medical English) within a specialised domain (e.g. Western medicine) that has its own history:

An SL is an "intentionalised" form of a natural language that puts its communicative function at the service of the purpose of the domain among specialised communities. [...] Specialised languages need not be highly technical or abstruse to qualify as such, the major criterion is that their communicative capacities are not deployed for communication's sake, but are harnessed to the service of the purpose of the domain. [Van der Yeught 2016: 52]

Within a specialised domain (e.g. medicine), a specialised language (e.g. the language of medicine) divides into different space- and time-depending languages (e.g. the modern English language of medicine) which are spoken by politically-structured national communities (e.g. British doctors) and are culture-bound (e.g. evidence-based medicine).

Within an SL, the lexicon conveys "a lot about the directness of the domain, its intentionality, its objects and their aspectual shapes and its related background abilities" [Van der Yeught: 54]. Hence, a word like "theatre", used in British medical English, summons the history of $18^{\text {th }}$ century European surgery, where medical amphitheatres permitted the viewing of surgical operations performed on live patients, and draws its specialised meaning ('a place where surgeries are performed') from the context of its utterance (e.g. a medical context). Therefore, the specialised lexicon will be properly interpreted solely within the frame of its specialised domain.

When we analyse the lexicon of modern medical English from a synchronic perspective, we observe two main types of intentionality: concision and privacy. Indeed, in modern Western medicine, looking after the sick demands that the healthcare professional be both efficient and thoughtful. To meet either need, the language of medicine resorts to abbreviations. For instance, OR for "Operating Room" in American English serves the purpose of concision. By being difficult to decipher, Hi5 to designate an HIV-positive patient serves the purpose of privacy. But when we study the lexicon from a diachronic perspective, we notice that what characterises medical English first and foremost is loanwords.

7 Our study examines how the English medical lexicon was partly built on borrowings from French. Lexical borrowing is by far the most frequently attested language contact 
phenomenon and is common to all languages (Tournier [2004]). The term "loanword" as used in this paper is to be understood as a word of foreign origin that entered a language via "transfer or copying processes, whether they are due to native speakers adopting elements from other languages into the recipient language, or whether they result from non-native speakers imposing properties of their native language onto a recipient language" (Haspelmath \& Tadmor [2009: 36]).

(he centuries, the English language of medicine has continually been borrowing words from other languages as new discoveries were being made and new concepts were being developed. Almost from its origin, English has received an influx of words from Greek. In the Middle Ages, the main source language was Latin, although many Latin words got into English by way of Anglo-Norman (Dirckx [1983]).

But medical English has borrowed its terminology from many other source languages: Arabic, often through Latin, as with "alcohol" from al-kuhul 'kohl', and "nuchal" from nukha 'spinal marrow'; German as with "angst" 'a feeling of anxiety, apprehension and insecurity', and mittelschmerz 'ovulation pain', from a word meaning 'middle pain'; Italian as with "malaria" from mal'aria 'bad air', and "influenza" from a word meaning 'an outbreak of an epidemic', itself from Medieval Latin influentia, as astrologers believed that epidemics were due to the influence of the stars; Spanish as with "pinta", a tropical infectious skin disease, from a word meaning 'spot', and "turista", a diarrhoea affecting travellers; Portuguese as with "albino" 'white'; Hindi and Urdu as with "kala-azar", a form of leishmaniasis, from kālā āzār 'black disease'; or Japanese as with "sodoku", an infectious disease transmitted by rats, from so 'rat' and doku 'poison' (Faure [2012]).

Another type of loanword that has been greatly contributing to enriching the English medical lexicon is the eponym. It is usually associated with the discovery of a body-part (e.g. "Bartholin's glands", after the Danish anatomist, Caspar Bartholin (1655-1748)), the invention of an instrument (e.g. "Foley's catheter", after Frederic Foley (1891-1966), an American urologist who produced the original design in 1929, and "stent", after Charles Stent (1807-1885), an English dentist), or a technique (e.g. "Pfannenstiel's incision", a type of abdominal surgical incision, after the German gynaecologist, Hermann Pfannenstiel (1862-1909)). The eponym is often also related to the first clinical description of a disease (e.g. "Hansen's disease" after Gerhard Hansen (1841-1912), a Norwegian physician), or to the first identification of a pathogen (e.g. "Bartonella" after Alberto Barton (1871-1950), a Peruvian scientist).

11 Eponyms can be abbreviated: "Pap smear" or "Pap test", after the Greco-American physician Georgios Papanikolaou (1883-1962), who invented the test, or "CJD", from "Creutzfeldt-Jakob disease", after the two German neurologists, Hans Creutzfeldt (1885-1964) and Alfons Jakob (1884-1931). They can also be at the root of new words through derivative processes: "bartholinitis", the inflammation of the eponymic glands, or "parkinsonian" and "parkinsonism", from "Parkinson's disease", after the English surgeon, James Parkinson (1755-1824).

12 Although loanwords can be studied from many different perspectives including phonetics and phonology, we decided to focus on semantics and morphology, whilst insisting on the underlying historical and scientific background.

13 The French loanwords referred to in this paper were manually retrieved from specialised paperback and online medical dictionaries and glossaries whose list is included in a separate subsection. For lack of space, we were not able to cover every entry. Therefore, 
we inserted a table (see appendix, table 1) that lists all the terms we came across in our research. While we were addressing the question of eponyms, we decided to exclude people that, although Francophones, were not of French nationality or did not conduct their research in France, as we wished to put their work into the context of the history of France. Yet, we could not go through all the French people whose names have marked the English language of medicine as the question of eponyms is not the sole subject of this paper. Therefore, we listed and classified them according to their speciality in a table (see appendix, table 2). Both tables are to be found at the end of this paper.

For the "Norman conquest" section, the words we selected were extracted from the online Anglo-Norman Dictionary, which is updated regularly and is linked to an extensive database of related texts. In addition, the entries are semantically structured. AngloNorman spelling was not fixed at the time, which explains that some words may have different spellings (e.g. trouble / truble / torble 'trouble, disturbance'). We reproduced the different spellings only when we considered the difference to be of interest. We doublechecked all the entries using the Online Etymology Dictionary, The American Heritage Dictionary of Indo-European Roots and the Centre National de Ressources Textuelles et Lexicales. For the "French medical revolution(s)" section, we used the Dorland dictionnaire médical bilingue français-anglais and the Dictionary of Medical Terms. We selected these two sources for their reliability, regular updates and comprehensiveness. We cross-referenced all the entries of both sections using Memidex. For the "Eponyms" section, we used the Dictionnaire des éponymes médicaux français-anglais (Van Hoof [1993]) and Stedman's Medical Eponyms whose terms we cross-checked with specialised websites. The eponyms we report are the ones that are still in use in the present medical English language. We discarded those that were obsolete. We chose to write the eponyms with /'s/ when there was only one name-giver, thereby voluntarily ignoring the debate around the use of "synthetic genitive", although most American publications use $\mathrm{N} \varnothing \mathrm{N}$ form (Narayan et al. [2009]).

Definitions were borrowed from the online TheFreeDictionary's Medical dictionary, the Dictionary.com, Merriam-Webster Dictionary, Cambridge Dictionary, Lexicon of psychiatric and mental health terms, Medical terminology daily, MedicineNet and Orphanet. All these databases were chosen for their clarity and accuracy.

16 To facilitate reading, we opted for a typology by semantic field (e.g. diseases, body parts, medicines, etc.) in the "Norman conquest" section, and by medical speciality (e.g. obstetrics, paediatrics, etc.) in the "French medical revolution(s)" and the "Eponyms" sections. We chose to introduce translations and definitions with single quotes as opposed to double quotes (e.g. "Plaster of Paris" 'a fine white plaster used to make plaster casts').

\section{The Norman conquest of England and medicine in the Middle Ages}

17 After the Norman Conquest at the very beginning of the $11^{\text {th }}$ century, the use of the vernacular language as the language of medicine seems to have been eclipsed by Latin and Anglo-Norman. Indeed, there exists a considerable amount of medical and surgical treaties written in Anglo-Norman dating mostly back to the first half of the $13^{\text {th }}$ century onwards (Rothwell [1976]). Most of the words of French origin that appear in these treaties are still in use in today's medical English whether in their original form (e.g. 
"malaise") or after having undergone either morphological (e.g. "anguish") or semantic changes (e.g. "brace").

Many medical words, although of Latin and Greek origin, entered the English language via French and more precisely via Anglo-Norman (e.g. "alienation" 'delirium, delusions' (late 14c.) from the Latin alienare in a secondary sense 'deprive of reason, drive mad', and Old French alienacion).

About the middle of the $12^{\text {th }}$ century, the faculty of Montpellier became known as the centre of medical activity. In approximately the same period, medicine emerged as a discipline at the University of Paris (Siraisi [1990]). Physicians from all over Europe and especially from England would train in France.

Many of the words borrowed from Anglo-Norman correspond to the diseases that were prevalent at that period, most of which were infectious such as leper (mid-13c.), which could designate the disease or the affected person, leprosie (late 14c.) (mod. Eng. "leprosy"), and leprous (from Old French lepros 13c.); and peste (16 c.) 'pestilence', plague, 'fatal epidemic disease', which has survived as "pest" in today's English to designate 'an insect or small animal that is harmful'. The more general term "malady" (from old French maladie) itself entered the English language in the $13^{\text {th }}$ century.

These infectious diseases often had skin manifestations that were designated by words borrowed from French: cancre (12c) 'abscess, sore, ulcer, tumour', which has given the words "canker" 'a gangrenous or ulcerous sore, especially in the mouth', and "chancre" 'the initial lesion of syphilis', in modern English; pustule (late 14c.) 'pustule, boil'; felon (14c.) 'abscess, ulcer, boil', a word that is now synonymous for 'whitlow'; ulcer (from Old French ulcere 15c.) 'a break in skin or mucous membrane'; fester (late 14c.) 'fistula, ulcer, tumour, sore', which still exists as a verb; and polipe (15c.) 'polypus, growth or ulcer in the nose', which has been kept in modern English ("polyp") but with a much larger meaning scope - i.e. 'a small mass of cells that grows in the body'.

Diseases of the Middle Ages also caused symptoms such as "fever", a word whose spelling was influenced by Old French fievre, although it already existed in Old English (fefor / fefer ); "phlegm" (late 14c.), a word that comes from Old French fleume 'viscid mucus', itself from Late Latin phlegma, one of the four humours of the body, from Greek phlegma 'humour caused by heat'; "flux" (late 14c.), from old French flus that meant 'flowing, rolling, bleeding'; and “noise” (early 13c.), from Old French noise 'brawl, uproar'.

Some of the words that designate symptoms have undergone a semantic change such as angu(o)isse (13c.), which used to be defined as 'pain, difficulty, a painful area', and now means, in its modern form, “anguish", 'great mental suffering, anxiety', although it still refers to 'extreme physical pain' too. Others are still in use in modern English but have become obsolete such as apoplexy (14c.), from Old French apoplexie, which is nowadays being eclipsed by terms like "stroke" and "cerebrovascular accident".

4 The three adjectives "arthritic" (mid-14c.), "paralytic" (14c.) and "pleuritic" (14c.) come respectively from old French artetique, paralitique ('palsied, experiencing muscular weakness', itself from paralisie, palesie and parle(i)sie 'paralysis, palsy, muscular weakness', which we find in modern English in the form "paralysis" and "palsy"), and pleuretique ('suffering from pleurisy' from Old French pleurisie and Anglo-Norman pleuresie 'pleurisy, inflammation of the pleura, lung disease').

The medieval physicians also dealt with all sorts of mental illnesses, which were often designated by words borrowed from French. Some of these words have undergone 
modifications in modern English: folie (early 13c.) 'madness, stupidity', a word that was anglicised into "folly"; lunetie (late 14c.) 'lunacy, (state of) frenzy induced by the moon'; maniaque (15c.) 'insane' (mod. Eng. "maniac" and "manic"); demency (from old French démence) and its verb dement (16c.), which is used, in its adjective form "demented", in modern English; rage (14c.) (from Old French raige, rage) means 'rage, madness, violent pain', whereas the word "rabies" (late 16c.) that designates the viral disease itself was borrowed directly from Latin rabiēs; and agony (from old French agonie, aigoine 'anguish, terror, death agony'), which was first introduced in the $14^{\text {th }}$ as "mental suffering" and which took its sense of 'extreme bodily suffering' in the $17^{\text {th }}$.

In certain cases, the words that were borrowed from French got anglicised and later on, francised again: "migraine" (late 14c.) took on the form megrim, from old French migraigne, and was re-spelled "migraine" in Middle English on the French model.

Some disease names were metonymic. For instance, goute (13c., modern English "gout" from old French gote / gout 'drop') was so named because the condition was thought to be caused by drops of vicious humours into the joints and tissues. Likewise, the word jaundyce (14c., modern Eng. "jaundice", from old French jaunisse / jaunyce) comes from the adjective jaune 'yellow'.

Many words that refer to body-parts and that are still in use in modern English are derived from French. The word "anatomy" (14c.) itself entered the English language through French anatomie, from Latin anatomia, from a Late Greek word meaning 'dissection'. Among the viscera, the Anglo-Norman words buel / boel (late 14c.) 'intestines, innards', from Latin botulus 'sausage', which is used in modern English in the form of "bowel(s)", designated the intestine(s).

Other more general anatomical terms also come from French such as "muscle" (late 14c.), which derives from muscel 'muscle, sinew', itself from Latin musculus 'muscle', literally 'little mouse', by analogy with the animal; "nerve" (late 14c.) from old French nerf; "joint" (early 15c.) from Anglo-Norman joynt(e) 'joint, knuckle' from old French joint; "trunk" (mid-15c.) from Anglo-Norman trunc from Old French tronc 'torso of the body'; "loin" (early 14c.) from old French loigne 'hip, lumbar region'; and "genitals" (late 14c.) from Anglo-Norman genitales 'sexual organs'. Two words that still relate to the throat in modern English come from French: "gullet" (14c.) from Old French goulet 'throat'; and "gargle" (16c.) from Old French gargouiller 'throat'.

Like many other words in modern English, some have lost the original initial /e/: "spleen" (13c.) comes from Anglo-Norman espleen from old French esplen, from Latin splen , from Greek splēn; and "stomach" (early 14c.) from Anglo-Norman estomac(h), from old French stomaque / estomac, from Latin stomachus 'gullet, oesophagus, stomach'.

Some words have seen their meaning scope reduced: jou(w)e (late 14c.), from old French joue / joe 'cheek, jaw', used to mean 'cheek, jaw, jawbone' and now, in its form "jaw", designates the cartilaginous or bony structures that border the mouth.

Some words that were originally anatomical have evolved into notions that have become more abstract: coer (late 14c.) from Old French cuer / coeur (mod. English "core") used to designate the heart and now means 'the central part or the essential meaning of something'.

Some words that still sound Latin entered the English language through French such as "anus" from anel / anus, itself from Latin anus 'ring, anus'; and "dens" from dens / dent 'tooth', itself from Latin dens 'tooth'. 

'body', from old French corps / cors, now designates 'a corpse' (first attested occurrence in 1542); Anglo-Norman brace (mid-14c.) 'arm', from Old French, now means, when singular, 'an orthopaedic appliance or apparatus applied to the body to support its weight and to correct or prevent deformities', and, when plural, 'an orthodontic appliance'; and old French cane (late 14c.) 'reed, cane' is now 'an assistive device that provides partial support and balance'. diet, medication and surgery. Inherited from the physic gardens with medicinal plants that were grown in the $10^{\text {th }}$ century's monasteries, remedies were quite numerous and needed to be preserved in "pharmacies", a word that was introduced late 14c. from old French f/pharmacie 'medicine, treatment, purgative'. In France, only after 1484 did apothecaries ${ }^{5}$ acquire a status that made them different from grocers ${ }^{6}$.

Like medicine, pharmacology was based on humourism, and remedies mostly came in the form of preparations to be applied on the skin and were designated by French words: oignement (late 13c.) 'ointment, salve, unguent', borrowed from Latin unguentum; 'balm', from Old French baume (12 c.); paste (14c.) 'pasty substance applied to the skin for medicinal purpose', from old French, from late Latin pasta 'medicinal preparation in the shape of a small square'; and Anglo-Norman grece (14c.) from old French gresse 'fatty substance, ointment, unguent' (mod. Eng. "grease").

Medieval pharmacopoeia also contained remedies made of poudre (early 13c.) 'pulverised medicinal preparation', from Old French (mod. Eng. "powder"); pelote (mid-14c.) 'medicinal ingredients compressed into a bolus or pill', from old French (mod. Eng. "pellet"); and poisun / poison (13c.), derived from Old French puison / poison 'a potion, a harmful medicinal drink'.

Their galenic formulation also bore names borrowed from French: dragée ${ }^{7}$ 'a sweet medicinal preparation for the stomach', from old French dragie (late 17c.); fiole / viole (late 14c.) from Old French fiole (mod. Eng. "vial"); pessarie (14c.) 'vaginal suppository' (modern English "pessary"); ampoule (13c.) (modern English "ampoule" with two alternative forms "ampul" and "ampule") from old French ampole 'flask, vial'; pillule (15c.) (modern English "pill") borrowed from Latin pilula 'small round body'; and pokete 'small cloth bag containing a medicinal preparation' (mid-14c.), a diminutive of old North French poke 'bag' (modern English “pocket”).

According to Nancy Siraisi (1990), from the $13^{\text {th }}$ century, surgery (a word from Old French cirurgerie (14c)) in the sense of treatment by incision, cautery, or physical manipulation was normally relegated to barbers, barber-surgeons and surgeons (a word from old French serurgien / cirurgien).

Surgeons had very limited surgical techniques: cauterie (15c.) (from Old French cautère, a word that gave out "cautery" and "cauterisation" in modern English), phlebotomy (13c.) (from old French flebotomie 'bloodletting'), and trepanning (16c.) (from old French trephination, itself from trepan).

The essential surgical equipment consisted of instruments for making incisions and straightening broken limbs, among which we find many words of French origin such as "chisel" (early 14c.) from old French cisel; "drape" (15c.) from old French draper, from drap 'a piece of cloth'; “tourniquet" (17c.) from old French torner 'turn', that is still in use 
in modern English whereas it has disappeared from modern medical French; "lancet" (late 14c.) from Old French lancette 'small lance'; and "trepan" (14c.).

Medieval medicine was also marked by the development of hospitals (a word from old French hospital / ospital whose meaning evolved from 'a charitable institution for the needy' in early $15^{\text {th }}$ century to 'an institution for sick or wounded people' in the $16^{\text {th }}$ century). Still under the responsibility of the church, these institutions first aimed at the homeless became progressively places where sick people could be taken care of, treated or observed.

38 Although medieval medicine drew on the ancient heritage of Greek medicine, it participated in the refinement of the technical vocabulary and created a favourable environment in which the medicine of the Enlightenment could develop.

\section{The French medical revolution(s)}

The Age of Enlightenment, whose foundation was laid by the French philosopher René Descartes' (1596-1650) rationalist philosophy and which dominated Europe in the $18^{\text {th }}$ century, represented a shift in medicine. This shift accompanied the rejection of both the religious conceptions and the medical doctrines that had prevailed so far. Indeed, with the progress made in anatomy and physiology thanks to dissection and microscopy, humourism was almost abandoned to the benefit of mechanism. Part of this paradigm shift in medicine came from the work by the French Antoine de Lavoisier (1743-1794), who, with his chemical experiments, helped understand basic functions such as respiration, perspiration and digestion. Words such as oxygène and azote ("oxygen" and "azote/nitrogen" in modern English) were his creations.

Among the medical specialities that were strongly influenced by the French at that time, there were psychiatry and surgery. Philippe Pinel (1745-1826) contributed to the classification of mental disorders by carefully observing his patients' behaviour and introduced new words like polypharmacie (mod. Eng. "polypharmacy"). He also gave a new definition for existing terms such as "melancholia", "dementia" and "mania". In his wake, the two physicians Charles Lasègue (1816-1883) and Jean-Pierre Falret (1794-1870) conceptualised a psychiatric syndrome in which symptoms of a delusional belief and hallucinations are transmitted from one individual to another and which they named "folie à deux", a term that is still in use in modern English.

Two other terms that are of prime importance in psychiatry namely "grand mal", which defines severe epilepsy characterised by seizures in which there is an abrupt loss of consciousness, and "petit mal", which designates epilepsy characterised by mild seizures, came into use in the English language around 1870 through French.

Other French terms that are presently used in the modern English of psychiatry date back to that period: "(la) belle indifférence", described in DSM-IV", refers to 'an apparent lack of concern shown by some patients towards their symptoms'; "abandon", 'a letting loose, freedom from self-restraint, surrender to natural impulses'; "bouffée délirante", which, in DSM-IV, is described as a 'brief psychotic disorder'; "déjà vu" (1903), which designates 'the illusion of remembering scenes and events when experienced for the first time' and means 'already seen', and all its derived terms ("déjà pensé" 'already thought'; "déjà entendu" 'already heard'; "déjà lu" 'already read') that appeared later; "écho de la pensée" or "echo de la pensee" (lit. 'thought echo'), which is defined as 'the phenomenon 
in which a patient hears voices which echo thoughts just after they have occurred to them'.

Other notable psychiatric terms are "idée fixe" (1836), which describes 'an idea that dominates one's mind especially for a prolonged period'; “tic" (1822), 'a repetitive movement that is difficult, if not impossible to voluntarily control' and its derived term "tic douloureux", 'a painful disorder of the trigeminal nerve, characterised by severe pain in the face and forehead', which was first reported in 1800, from ticq, which used to designate "a twitching disease of horses"10; and "voyeur" and its derived term "voyeurism", described as "a paraphilia in which the preferred method of achieving sexual excitement is by the repetitive watching of unsuspecting people who are naked, disrobing, or engaging in sexual activity'.

The French have played a major role in the independence of surgery as a speciality. Indeed, from the $16^{\text {th }}$ century to the $18^{\text {th }}$ century, all over Europe, the Fellowship of Surgeons was merged with the Barbers' Company. The independence of surgery was heralded by the French Ambroise Paré (1510-1590), a barber-surgeon who is considered to be the father of modern surgery. Originally a wound-dresser, he started his career on the battlefields where he gained his reputation by replacing cauterisation by ligatures, when amputating, and applying emplastrums ${ }^{11}$ instead of boiling oil on gunshot wounds. According to Lévy [1995: 19], he is believed to have been the first to use the word bistouri (modern English "bistoury") as 'a long, narrow-bladed knife, with a straight or curved edge and sharp or blunt point, used for opening or slitting cavities or hollow structures'. Yet, surgeons had to wait until 1743 when Louis XV ordered the complete separation between Saint-Côme ${ }^{12}$ practitioners and barbers (Ramsey [2002: 21]). Therefore, many words that designate major surgical procedures are inherited from French: "cerclage" (end of the $19^{\text {th }} /$ early $20^{\text {th }}$ ), which means 'encircling of a part with a ring or loop, as for correction of an incompetent cervix uteri or fixation of the adjacent ends of a fractured bone', from French cerclage 'encircling'; "debridement" (1839), which designates the removal of damaged tissue from a wound, from French débridement, literally 'unbridling'; and "lavage", which means 'washing out or irrigating an organ such as the stomach or the eye', from French lavage, from laver 'wash', and which came into use in the late $18^{\text {th }}$ century.

Surgical procedures required the invention of surgical instruments, many of which bear names borrowed from French: "bougie" (from bougie 'wax candle', itself from the Algerian town Bijiyah where wax trade had been long-established) was introduced in 1754 as a type of thin dilating surgical instrument which can be inserted into passages of the body; "curette", a word that refers to a thin spoon-like instrument used for scraping the inside of an organ, was introduced in 1753 from French curette, itself from curer 'scrape, cleanse'; "tampon" 'a plug of cotton to stanch a flow of blood (especially from the vagina)' was introduced in 1848, from French tampon 'plug', and also gave "tamponade", which designates 'a stoppage in the flow of blood in a vessel, caused either by the insertion of a tampon or by outside constriction', and which is still in use in "cardiac tamponade", 'the mechanical compression of the heart by large amounts of fluid or blood within the pericardial space that limits the normal range of motion and function of the heart'.

The French have also strongly influenced medical obstetrics with Ambroise Paré and his book on how to extract a foetus in case of breech presentation (Dachez [2012: 446]). In the mid-1 $17^{\text {th }}$ century, François Mauriceau (1637-1709) founded the first French school of obstetrics and became one of the masters of European obstetrics (Dachez [2012: 450]). 
We owe him "Mauriceau's manoeuvre", a method of delivering the aftercoming head in cases of breech presentation. But the best known is probably Jean-Louis Baudelocque (1745-1810) whose L'Art des accouchements (1781) marked obstetrical practices all over Europe.

Notable words used in obstetrics are "fourchette" (18c.) 'a fold of skin at the back of the vulva' from $f(o)$ urchure / fourchette, itself a diminutive of French fourche 'fork'; "cystocele" (from French cystocèle, itself from Greek kystis 'bladder' and kele 'tumor, rupture, hernia'), which first came into use in 1811; "accouchement" 'the action of giving birth to a baby' (from French accouchement 'delivery'); “accoucheur" 'midwife / man-midwife', which dates back to 1759 and comes from French accoucheur, itself from accoucher 'give birth' from couche 'bed'; "ballottement" (1830) 'a method of diagnosing pregnancy, in which the uterus is pushed with a finger to feel whether a foetus moves away and returns again', which comes from French ballottement 'tossing'; and "douche" (from French douche 'shower', itself from Italian doccia), which, in its meaning 'vaginal cleansing', was introduced in 1833.

The French physicians of the time also played a unique role in shaping the language of clinical medicine. "New methods such as percussion, mediate auscultation, and psychological evaluation were introduced, and autopsies became routine" [Weiner \& Sauter 2003]. René Laënnec (1781-1826), who practised medicine in Paris, invented a simple instrument that he coined stéthoscope (mod. Eng. "stethoscope"). In 1819, he wrote a treatise, De l'auscultation médiate (1819), describing many of the abnormal sounds in the heart and lungs that were revealed by his stethoscope and whose French names still pertain to the English medical terminology: "bruit", a word itself from old French bruit 'noise'; "rale", 'an abnormal crackling sound heard in the lungs', from râle, itself from râler 'groan'; "murmur", an unusual sound heard between heartbeats, itself from old French murmure 'murmur, sound of human voices' that already existed in the English language but with a different meaning; "souffle" 'a soft, blowing auscultatory sound'; and "rhonchus" that Laënnec coined from the Latinised form of Greek rhenkhos 'snoring'.

Many of the words used in modern physiotherapy are of French origin and come from that period: "massage" (1874) and "masseur" (1876) 'a man who works giving massages' from masser 'massage'; "effleurage" (1886) 'gentle rubbing with the palm of the hand' from effleurer 'touch lightly', from fleur 'flower'; and "petrissage" 'kneading' from pétrir 'knead'.

50 Likewise, some modern English words used in dermatology were borrowed from French: the term "café au lait" 'coffee with milk' is reported in English in $1763^{13}$. Yet, its first known use as a modifier used in medical terminology (e.g. "café-au-lait spots" or "caféau-lait macules", often abbreviated as "CAL") dates back to 1946. The term designates 'any of the brown spots usually on the trunk, pelvis, and creases of the elbow and knees that are often numerous in neurofibromatosis' and can be found with or without hyphens ("café au lait spots") and with or without the accent ("cafe au lait spots"). Another French dermatological term "peau d'orange", sometimes used as a pleonastic hybrid (e.g. "peau d'orange skin"14) and which designates 'a pitted or dimpled appearance of the skin, especially as characteristic of some cases of breast cancer or due to cellulite', dates back to the same period (1896). 


\section{Eponyms}

51 Eponymisation "honours a person who makes a certain contribution to our culture" (Garfield [1983: 384]), and medicine has a particularly rich eponymic tradition. So much so that Matteson and Woywodt [2006] coined the term "eponymophilia".

Out of the thousands of doctors and scientists that have given their names to a condition, technique, instrument or anatomical part in the medical language we counted 231 namegivers of French origin. Due to lack of space and because this paper does not deal with eponyms exclusively, we selected the most prominent French contributors ${ }^{15}$.

Some of these contributors have given more than one eponym but we decided to keep the most widely known such as "Babinski's reflex/sign", the plantar reflex, which occurs in infants when the sole of the foot is firmly stroked and whose persistency after age two is a sign of a neurological disorder, after the French neurologist Joseph Babinski (1857-1932), whose name is associated with a dozen other eponyms.

The French people of the mid-19 $9^{\text {th }}$ century would have many given names (e.g. Georges Albert Édouard Brutus Gilles de la Tourette). We kept the one - usually the first - by which the person was best known (e.g. Georges Gilles de la Tourette, Gilles de la Tourette being the family name), unless the given names were hyphenated (e.g. Jean-Martin Charcot).

We decided not to classify the eponyms according to their dates of creation, although our analysis confirms that most medical eponyms were coined during the $19^{\text {th }}$ century (Sournia [1997]).

We observed that accent-carrying eponyms that are long-established and those that have recently entered the English language of medicine tend to lose their accent(s) (e.g. "Guillain-Barre syndrome" and "Aicardi-Goutieres syndrome"), making them part of the English terminology.

According to Hamburger [1982:137-138], there are three main reasons why the medical language resorts to eponymisation. The first is when the person, like Babinski who revolutionised the neurological examination, makes a discovery that turns out to be a major scientific breakthrough.

The second reason is when there is a need to distinguish between different variants of a same instrument (e.g. "Auvard's speculum", a type of vaginal speculum, named after the French obstetrician Pierre Auvard (1855-1941)) or technique (e.g. "Lisfranc's amputation", named after the French surgeon Jacques Lisfranc de St. Martin (1790-1847), which designates a type of amputation of the foot at the tarsometatarsal joint).

The third reason lies in the complexity of syndromes and diseases that would require long descriptive names to which eponyms used to be and are sometimes still preferred (e.g. "Ménétrier's disease", named after the French pathologist Pierre Ménétrier (1859-1935), versus "hypoproteinaemic hypertrophic gastropathy") or when these descriptive names are derogatory (e.g. "Achard-Thiers syndrome", named after Emile Achard, who was a French internist (1860-1944) and his colleague Joseph Thiers (1885-1960), instead of "diabetic bearded woman syndrome").

Among the 231 French name-givers, we counted only four women i.e. 1,7\%: Augusta Dejerine-Klumpke (1859-1927) who, although of American origin, did all her medical studies in Paris and has given her name to "Klumpke's paralysis", a type of brachial palsy 
in newborns; Charlotte Dravet (1936-), a French paediatric psychiatrist and epileptologist, who has given her name to "Dravet's syndrome", a rare genetic epileptic encephalopathy; Gabrielle Lévy (1886-1935), a French neurologist, who was the co-identifier of "RoussyLévy syndrome", also known as "hereditary areflexic dystasia", a rare genetic neuromuscular disorder; and, in 1954, the French dentist Éline Papillon-Léage, who contribued to the identification of "Papillon-Leage and Psaume syndrome", also known as "oral-facial-digital syndrome type 1" (OFD1), a syndrome seen only in females, with mental retardation and various anomalies.

We classified the 231 name-givers according to the main speciality to which they contributed. We noted that 59 people were neurologists and psychiatrists, which makes neuro-psychiatry the specialty in which the French have contributed the most. The two neurologists Georges Guillain (1876-1961) and Jean Barré (1880-1967) diagnosed two soldiers with what is still called "Guillain-Barré syndrome" or "Guillain-Barre syndrome" (GBS), a disorder in which the body's immune system attacks part of the peripheral nervous system.

Before them, Jean-Martin Charcot (1825-1893) was also a neurologist whose name is associated with at least 10 medical eponyms including "Charcot's foot/joint", "CharcotMarie-Tooth disease", "Charcot's triad" and "Charcot's disease" (now more widely known as "amyotrophic lateral sclerosis"), all neurodegenerative diseases. "Duchenne's muscular dystrophy" (DMD), a genetic disorder characterised by progressive muscle degeneration and weakness, has been named after another famous French neurologist: Guillaume Duchenne (1806-1875).

Georges Gilles de la Tourette (1857-1904), who was both a paediatrician and a neurologist, has marked the medical language with "Tourette's syndrome" (TS), a neurological disorder characterised by repetitive, stereotyped, involuntary movements and vocalisations. Pierre Broca (1824-1880) is best known for his research on "Broca's area", a region of the frontal lobe that has been named after him.

Forty-six French people have given their names to terms pertaining to the field of surgery such as Guillaume Dupuytren (1777-1883), a French anatomist and military surgeon, to whom medical English owes the terms "Dupuytren's contracture", where one or more fingers remain permanently bent in a flexed position, and "Dupuytren's fracture", which describes a variety of bimalleolar ankle fractures. Joseph Malgaigne (1806-1865) and Auguste Nélaton (1807-1873) were surgeons and colleagues. Both have marked the medical language with respectively "Malgaigne's fracture", a vertical pelvic fracture with bilateral sacroiliac dislocation and fracture of the pubic rami, and "Nélaton's dislocation", a dislocation of the ankle in which the distal ends of the tibia and fibula are separated. The latter also invented eponymous surgical instruments: "Nelaton's ${ }^{16}$ catheter", a term still in use, and "Nélaton's (bullet) probe", which got famous as it was used by the doctors during Lincoln's final night to ascertain the depth and path of the bullet in his head. Twenty-five French people have contributed to dermatology among whom HenriAlexandre Danlos (1844-1912), who participated in the identification of "Ehlers-Danlos syndrome", a group of inherited disorders that affect connective tissues. Ophthalmology is a field in which the French have been quite prominent with 14 namegivers such as the ophthalmologist Jean-Marie Abadie (1842-1932) with "Abadie's sign of exophthalmic goitre", a medical sign characterised by spasm of the levator palpebrae superioris muscle seen in Graves' disease. But the French ophthalmologist that is best remembered is Jacques Daviel (1693-1762), who was a pioneer in cataract surgery. He was 
the first to perform an extracapsular cataract extraction (also called "Daviel's operation").

The French have also been pioneers in paediatrics, with 12 name-givers, among whom famous physicians like Antoine Marfan (1858-1942), who described a genetic disorder that affects the body's connective tissue and that is still known as "Marfan's syndrome" (MFS). Born 24 years after him, Robert Debré (1882-1978), a French paediatrician and bacteriologist, has his name associated with a rare disorder characterised by an association of muscular pseudohypertrophy and hypothyroidism in children and called "Kocher-Debré-Semelaigne syndrome" (KDS). The largest paediatric hospital in Paris has been named after him.

Another very good illustration of both the presence of French terminology and of French eponyms in modern medical English is "Lejeune's syndrome" after the French paediatrician and geneticist Jérôme Lejeune (1926-1994), who was the first to describe this rare genetic disorder, which he named "cri-du-chat syndrome" ${ }^{17}$, a French term that is still in use in modern English and which means 'cat cry', the disorder being characterised by a high-pitched cry.

Although the French were not many to contribute to bacteriology, a field dominated by the Germans (e.g. Escherichia coli after Theodor Escherich; Koch bacillus after Robert Koch; Ehrlichia after Paul Ehrlich; Bilharzia after Theodor Bilharz, etc.) with only eight namegivers, they have marked the specialty durably: Louis Pasteur (1822-1895), who was one of founding fathers of medical microbiology, to whom we owe the terms "Pasteurella", a genus of Gram-negative anaerobic bacteria, and "pasteurisation", a process that kills bacteria in food, drinks or beverages; Albert Calmette (1863-1933) and Camille Guérin (1872-1961), who developed a vaccine against tuberculosis, still called BCG, an abbreviation of "Bacillus Calmette-Guerin"; Fernand Widal (1862-1929), who invented "Widal test" to diagnose typhoid fever; Alexandre Yersin (1863-1943), a Swiss but naturalised French physician and bacteriologist, after whom the bacillus responsible for the bubonic plague, which he discovered, was named (Yersinia pestis); Louis-Charles Malassez (1942-1909), who identified the genus Malassezia; and more recently, Robert Debré, who has given his name to "Debré's phenomenon", which, in measles, designates the failure of the rash to develop at the site of immune serum injection.

In hepatology, we retained Augustin Gilbert (1858-1927) with "Gilbert's syndrome", a common, harmless liver condition in which the liver does not properly process bilirubin; and René Laënnec with "Laennec's cirrhosis", which is also known as "alcoholic cirrhosis".

Gastroenterology has been marked by Jacques Caroli (1902-1979), who was the first to describe two rare congenital disorders of the intrahepatic bile ducts, both characterised by dilatation of the intrahepatic biliary tree and named "Caroli's disease" and "Caroli's syndrome".

Among the eight French people that are known to have contributed to otorhinolaryngology, we retained Prosper Ménière (1799-1862) whose name has been given to "Ménière's disease" or "Meniere's disease" (MD), a disorder of the inner ear; and Jean Vincent (1862-1950), a French bacteriologist, who identified a progressive painful infection with ulceration, swelling and sloughing off of dead tissue from the mouth and throat due to the spread of infection from the gums called "Vincent's gingivitis" or, in its non-eponymous vernacular form, "trench mouth" and, in its medical form, "necrotising ulcerative gingivitis". 
67 In cardiology, out of the six known name-givers, only Étienne-Louis Fallot (1850-1911) with "tetralogy of Fallot" (TOF), a congenital heart defect responsible for blue baby syndrome, and Louis Vaquez (1860-1936) with "Vaquez's disease", also known as "polycythemia vera", have marked the English language of medicine durably.

In a closely related field, Maurice Raynaud (1834-1881) is to be remembered for "Raynaud's syndrome" or "Raynaud's phenomenon", a common condition that affects the blood supply to certain parts of the body - usually the fingers and toes.

68 Finally, forensic medicine has strongly been influenced by the work of Auguste Tardieu (1818-1879), the pre-eminent forensic medical scientist of the mid-19 ${ }^{\text {th }}$ century, to whom we owe the term "Tardieu's spots" or "Tardieu's ecchymoses", subpleural and subpericardial petechiae or ecchymoses, as observed in the tissues of persons who have been strangled, or otherwise asphyxiated.

69 Another classification - according to the name-giver - distinguishes those eponyms in which the name-giver is a physician or a scientist from those in which the name-giver is a patient. Studies shows that $4 \%$ of the eponyms are derived from a patient's name (Lončar \& Ostroški Anić [2014]), but we found none of French origin.

70 Although there is a marked tendency to replace eponyms by orthonyms (Turnpenny \& Smith [2003]; Woywodt \& Matteson [2007]; Whitworth [2007]), we found some recent eponyms such as "Aicardi's syndrome", a rare neurodevelopmental disorder named after Jean Aicardi (1926-2015), a world-renowned physician and child neurologist, whose name is also associated with "Aicardi-Goutieres syndrome" (AGS), a genetic disorder that he identified with his colleague Françoise Goutières in 1984.

\section{Conclusion}

71 The exact number of French loanwords in English is difficult to estimate. A computerised survey of about 80,000 words from the Shorter Oxford Dictionary ( $3^{\text {rd }}$ edition) (Finkenstaedt \& Wolff [1973]) found that around 30\% were of French origin. Other sources mention figures that range between $45 \%$ and $55 \%$. Be that as it may, it appears that French is the English lexicon's primary source language.

The language of medicine consists of words most of which were borrowed from Greek and Latin. The English language of medicine is no exception, although, as mentioned in our study, some of these words have entered English via French.

Our study highlighted the bulk of French loanwords in the medical lexicon over two main periods of time, namely that of the Anglo-Norman period, during which the words that were infused form the basic vocabulary, and that of the French medical revolutions of the $18^{\text {th }}$ and $19^{\text {th }}$ centuries marked by the importation of words related to scientific breakthroughs. Because eponyms are an important part of the medical lexicon, we devoted a whole section to terms named after famous French anatomists, physicians and surgeons, while singling out the specialities in which the French were ahead in Europe. Our study has shown that French is a major source language for medical English, and should help put the much criticised anglicisation of modern medical French into perspective (Faure [2010]). 


\section{BIBLIOGRAPHY}

ALCARAZ Maria Angeles, 2009, "Medical English: a short study of Spanish borrowings", Lebende Sprachen 50 (2), 58-61.

BAETHGE Christopher, 2008, “Die Sprachen der Medizin”, Deutsches Ärzteblatt 3, 37-40

BALLESTERos Fernández, 2003, “El lenguaje de los médicos. El médico interactivo”, Diario electrónico de la sanidad, 892-910, http://www.medynet.com/elmedico/informes/informe/

lenguagjemedico.htm

CHIRA Dorin, 2000, "French loanwords in the English lexicon”, Studia Universitatis Babeú-Bolyai, Philologia XLV, 113-120.

CHIROL Laure, 1973, Les « mots français » et le mythe de la France en anglais contemporain, Paris :

Klincksieck.

DACHEZ Roger, 2012 [2008], Histoire de la médecine, Paris : Tallandier.

DIRCKX John, 1983 [1976], The Language of Medicine, its Evolution, Structure and Dynamics, New York: Praeger.

DIRCKX John, 2001, “The synthetic genitive in medical eponyms: Is it doomed to extinction?", Panace@ 2 (5), 15-24.

DOBRIĆ Katja, 2013, “Creating medical terminology: From Latin and Greek influence to the influence of English as the current lingua franca of medical communication", JAHR-European Journal of Bioethics 4 (7), 493-502.

FAURE Pascaline, 2015, « La langue du patient, de l'archaïsme à l'orthonyme : analyse comparative français/anglais », Les Cahiers de Lexicologie 106 (1), 213-228.

FAURE Pascaline, 2012, L'anglais médical et le français médical : analyse linguistico-culturelle et modélisations didactiques, Paris : Editions des Archives Contemporaines.

FAURE Pascaline, 2010, « Des discours de la médecine multiples et variés à la langue médicale unique et universelle », ASp 58, 73-86.

FINKENSTAEDT Thomas \& WOLFF Dieter, 1973, Ordered Profusion: Studies in Dictionaries and the English Lexicon, Heidelberg: Carl Winter.

FORTUINE Robert, 2001, The Words of Medicine: Sources, Meanings, and Delights. Illinois: Charles C. Thomas.

GARFIELD Eugene, 1983, "What's in a Name? The Eponymic route to immortality", Essays of an Information Scientist 6, 384-395.

GUTIÉRREZ Rodilla, 1997, "The influence of English in Spanish medical language”, Medicina Clínica Barcelona 108 (8), 307-313.

HAMBURGER Jean, 1982, Introduction au langage de la médecine, Paris : Flammarion.

HASPELMATH Martin \& TADMOR Uri, 2009, Loanwords in the World's Languages: A Comparative Handbook , De Gruyter Mouton. 
KERESZTES Csilla, 2013, English Language Contact-Induced Features in the Language of Medicine: An Investigation of Hungarian Cardiology Discharge Reports and Language Attitudes of Physicians and Patients, Peter Lang.

LAËNNEC René, 1819, De l'auscultation médiate ou traité du diagnostic des maladies des poumons et du cœur, fondé principalement sur ce nouveau moyen d'exploration, Paris : Brosson et Chaudé, http:// gallica.bnf.fr/ark:/12148/bpt6k5550316g

LÉVY Isabelle, 1995, Histoire anecdotique des instruments médicaux : De l'abaisse-langue aux ventouses, Lyon : Editions Josette.

LONČAR Maja \& OSTROŠKI ANIĆ Ana, 2014, "Eponymous medical terms as a source of terminological variation", in BUDIN G. \& LUŠICKY V. (eds.), Languages for Special Purposes in a Multilingual, Transcultural World, Proceedings of the $19^{\text {th }}$ European Symposium on Languages for Special Purposes, 8-10 July 2013, Vienna, Austria, Vienna: University of Vienna, 36-44.

MATTESON Eric \& WOYwODT Alexander, 2006, "Eponymophylia in rheumatology", Rheumatology, 45, $1328-1330$.

NARAYAN Jana, SUKUMAR Barik \& NALINI Arora, 2009, "Current use of medical eponyms - a need for global uniformity in scientific publications", BMC Medical Research Methodology 9, 18, https:// bmcmedresmethodol.biomedcentral.com/articles/10.1186/1471-2288-9-18

NAVARRO Fernando \& HERNÁNDEZ F., 1992, "Palabras de traducción engañosa en el inglés médico", Medicina Clínica Barcelona 99, 575-580.

OTMAN Gabriel, 1989, « En Français dans le texte : étude des emprunts français en angloaméricain », French Review 63, 111-126.

PRINS Anton, 1952, French Influence in English Phrasing, Leiden: University Press.

RAMSEY Matthew, 2002 [1988], Professional and Popular Medicine in France 1770-1830, Cambridge: Cambridge University Press.

ROMAINE Suzanne, 1989, Bilingualism, Oxford: Basil Blackwell.

ROTHWELL William, 1976, "Medical and botanical terminology from Anglo-Norman sources", Zeitschrift für französische Sprache und Literatur 86, 221-260, http://www.jstor.org/stable/40616627 SARTORI Monica, 2013, "Excuse me, what does it mean?: A socio-linguistic analysis of patient information leaflets in doctor-patient interactions", http://tesi.cab.unipd.it/43946/1/ Tesi_magistrale_Monica_Sartori.pdf SCHULTZ Julia, 2012, Twentieth Century Borrowings from French to English: Their Reception and Development, Newcastle upon Tyne: Cambridge Scholars Publishing.

SIRAISI Nancy, 1990, Medieval and Early Renaissance Medicine, Chicago: The University of Chicago Press.

SOURNIA Jean-Charles, 1997, Langage médical français, Toulouse : Privat.

TAYLOR Robert, 2017, The Amazing Language of Medicine: Understanding Medical Terms and Their Backstories, Springer International Publishing.

TOURNIER Jean, 1985, Introduction descriptive à la lexicogénétique de l'anglais contemporain, Paris : Champion-Slatkine.

TURNPENNY Peter \& SMITH Ron, 2003, "Of eponyms, acronyms and ... orthonyms", Nature Reviews Genetics 4, 152-156. 
VAN DER YEUGHT Michel, 2016, “A proposal to establish epistemological foundations for the study of specialised languages", Asp 69, 41-63.

WEINER D.B. \& SAUTER M.J., 2003, “The city of Paris and the rise of clinical medicine”, Osiris 18, 23-42.

WHITWORTH Judith, 2007, “Should eponyms be abandoned? NO”, BMJ 335, 425.

WOYwoDt Alexander \& MATTESON Eric, 2007, "Should eponyms be abandoned? YES", BMJ 335, 424.

WULFF Henri, 2004, “The language of medicine”, Journal of the Royal Society of Medicine 97, 187-188.

\section{Dictionaries and lexicons}

Anglo-Norman Dictionary, http://www.anglo-norman.net/gate/

BARTOLUCCI Sue \& FORBIS Pat, 2005. Stedman's Medical Eponyms, Baltimore: Lippincott Williams \& Wilkins.

Cambridge Dictionary, http://dictionary.cambridge.org/fr/

Centre National de Ressources Textuelles et Lexicales, http://www.cnrtl.fr/

Dictionary.com, http://www.dictionary.com/

Dictionary of Medical Terms. 2005. London: ACB.

Dorland dictionnaire médical bilingue français-anglais / anglais-français. 2008, Paris : Elevier-Masson. Lexicon of Psychiatric and Mental Health Terms, http://apps.who.int/iris/ bitstream/10665/39342/1/924154466X.pdf

Medical Terminology Daily, https://clinanat.com/mtd

MedicineNet, https://www.medicinenet.com

Memidex, http://www.memidex.com/

Merriam-Webster, https://www.merriam-webster.com

Orphanet, http://www.orpha.net

TheFreeDictionary's Medical Dictionary, http://medical-dictionary.thefreedictionary.com/

The Online Etymology Dictionary, https://www.etymonline.com/

VAN HOOF, 1993, Dictionnaire des éponymes médicaux Français-Anglais, Louvain-la-Neuve : Peeters.

WATKINS Calvert, 1985, The American Heritage Dictionary of Indo-European Roots, Boston: Houghton Mifflin Harcourt.

\section{APPENDIXES}

\section{Appendix}


Table 1. Medical words of French origin still in use in Modern English

\begin{tabular}{|c|c|c|c|c|}
\hline Word & Domain & $\begin{array}{l}\text { Word (when } \\
\text { different) in } \\
\text { modern French }\end{array}$ & $\begin{array}{l}\text { Meaning } \\
\text { (when } \\
\text { different) in } \\
\text { modern } \\
\text { French }\end{array}$ & $\begin{array}{l}\text { Word in } \\
\text { modern } \\
\text { French } \\
\text { (when } \\
\text { different } \\
\text { meaning) }\end{array}$ \\
\hline abandon & psychiatry & & & \\
\hline accouchement & obstetrics & & & \\
\hline agony & general & agonie & $\begin{array}{l}\text { excruciating } \\
\text { pain }\end{array}$ & \\
\hline ambulance & general & & & \\
\hline ampoule & pharmacology & & & \\
\hline anguish & psychiatry & angoisse & & \\
\hline antivenin & general & & & \\
\hline anus & anatomy & & & \\
\hline apoplexy & general & apoplexie & & \\
\hline apothecary & pharmacology & apothicaire & & \\
\hline assay & general & essai & & \\
\hline azote & chemistry & & & \\
\hline bandage & surgery & & & \\
\hline belle indifférence & psychiatry & & & \\
\hline ballottement & obstetrics & & & \\
\hline balm & pharmacology & baume & & \\
\hline barbotage & neurology & & & \\
\hline bias & general & biais & & \\
\hline bistoury & surgery & bistouri & & \\
\hline bouffée délirante & psychiatry & & & \\
\hline bougie & $\begin{array}{l}\text { surgery/ } \\
\text { obstetrics }\end{array}$ & & & \\
\hline
\end{tabular}




\begin{tabular}{|c|c|c|c|c|}
\hline bouton & neurology & & & \\
\hline bowel & anatomy & intestins & & \\
\hline brace & orthopaedics & $\begin{array}{l}\text { minerve, attelle, } \\
\text { appareil dentaire } \\
\text { / orthopédique }\end{array}$ & & \\
\hline bruit & cardiology & & & \\
\hline burette & chemistry & & & \\
\hline cachet & pharmacology & & & \\
\hline café au lait spot & dermatology & tache café-au-lait & & \\
\hline caisson disease & general & $\begin{array}{l}\text { maladie des } \\
\text { caissons }\end{array}$ & & \\
\hline calorie & general & & & \\
\hline cancre & dermatology & & a dunce & un chancre \\
\hline canal & anatomy & & & \\
\hline capsule & anatomy & & & \\
\hline cartilage & anatomy & & & \\
\hline cauterisation & surgery & cautérisation & & \\
\hline cerclage & obstetrics & & & \\
\hline chamber & cardiology & chambre & & \\
\hline chancre & dermatology & & & \\
\hline chisel & surgery & ciseau & & \\
\hline cholera & $\begin{array}{l}\text { infectious } \\
\text { diseases }\end{array}$ & choléra & & \\
\hline cholesterol & general & cholestérol & & \\
\hline commode & general & & $\begin{array}{l}\text { a chest of } \\
\text { drawers }\end{array}$ & $\begin{array}{l}\text { une chaise } \\
\text { percée }\end{array}$ \\
\hline complaint & general & complainte & a type of song & une plainte \\
\hline confinement & obstetrics & & containment & \\
\hline congeal & general & congeler & freeze & solidifier \\
\hline
\end{tabular}




\begin{tabular}{|c|c|c|c|c|}
\hline contrecoup & general & & & \\
\hline corpse & general & cadavre & & \\
\hline corset & orthopaedics & & & \\
\hline couch & general & couche & $\begin{array}{l}\text { a layer/ bed/ } \\
\text { nappy/diaper }\end{array}$ & $\begin{array}{l}\text { une table } \\
\text { d'examen }\end{array}$ \\
\hline coup & general & & & \\
\hline couvade & psychiatry & & & \\
\hline cramp & general & crampe & & \\
\hline cri-du-chat syndrome & psychiatry & $\begin{array}{l}\text { syndrome du cri- } \\
\text { du-chat }\end{array}$ & & \\
\hline culdoscope & surgery & colposcope & & \\
\hline curette & surgery & & & \\
\hline curettage / curettement & surgery & curetage & & \\
\hline cuvette & chemistry & & & \\
\hline cystocele & urology & cystocèle & & \\
\hline debridement & surgery & débridement & & \\
\hline decease & general & décéder & & \\
\hline decoction & pharmacology & décoction & & \\
\hline deformed & general & déformé & & \\
\hline degeneration & general & dégénération & & \\
\hline deglutition & general & déglutition & & \\
\hline déjà vu & psychiatry & & & \\
\hline delivery & obstetrics & délivrance & & \\
\hline demented & psychiatry & dément & & \\
\hline denture & odontology & dentier & & \\
\hline detergent & surgery & détergent & & \\
\hline diarrhoea & gastroenterology & diarrhée & & \\
\hline diphtheria & ENT & diphtérie & & \\
\hline
\end{tabular}




\begin{tabular}{|c|c|c|c|c|}
\hline disease & general & désaise & unease & une maladie \\
\hline dislocation & $\begin{array}{l}\text { surgery/ } \\
\text { physiotherapy }\end{array}$ & & & \\
\hline dormant & $\begin{array}{l}\text { infectious } \\
\text { diseases }\end{array}$ & & & \\
\hline douche & pharmacology & & & \\
\hline dragee & pharmacology & dragée & & \\
\hline drape & surgery & drap & & \\
\hline echo de la pensée & psychiatry & écho de la pensée & & \\
\hline écraseur & surgery & & & \\
\hline effacement & obstetrics & & & \\
\hline effleurage & physiotherapy & & & \\
\hline engagement & obstetrics & & & \\
\hline engorgement & haematology & & & \\
\hline fatigue & general & & & \\
\hline feeble & general & faible & & \\
\hline felon & dermatology & félon & a traitor & un panaris \\
\hline flux & $\begin{array}{l}\text { infectious } \\
\text { diseases }\end{array}$ & & & \\
\hline folie à deux & psychiatry & & & \\
\hline fontanelle & obstetrics & & & \\
\hline fourchette & anatomy & & & \\
\hline fragile & general & & & \\
\hline friable & general & & & \\
\hline frotteurism & psychiatry & frotteurisme & & \\
\hline fugue & psychiatry & & & \\
\hline gauze & surgery & gaze & & \\
\hline gavage & psychiatry & & & \\
\hline
\end{tabular}




\begin{tabular}{|c|c|c|c|c|}
\hline gender & general & genre & & \\
\hline genitals & anatomy & $\begin{array}{l}\text { (parties) } \\
\text { génitales }\end{array}$ & & \\
\hline globule & haematology & & . & \\
\hline goitre & endocrinology & & & \\
\hline gouge & surgery & & & \\
\hline gout & metabolism & goutte & & \\
\hline grand mal & psychiatry & & & \\
\hline grattage & surgery & & & \\
\hline grippe & $\begin{array}{l}\text { infectious } \\
\text { disease }\end{array}$ & & & \\
\hline guillotine & surgery & & & \\
\hline hospice & general & & & \\
\hline hospital & general & hôpital & & \\
\hline idée fixe & psychiatry & & & \\
\hline idiot savant & psychiatry & & & \\
\hline impotence & general & & & \\
\hline infusion & pharmacology & & & \\
\hline innocent & general & bénin & & \\
\hline internment & psychiatry & internement & & \\
\hline intestine & anatomy & intestin & & \\
\hline jaundice & general & jaunisse & & \\
\hline joint & anatomy & & & \\
\hline lancet & surgery & lancette & & \\
\hline lavage & surgery & & & \\
\hline leprosy & $\begin{array}{l}\text { infectious } \\
\text { diseases }\end{array}$ & lèpre & & \\
\hline loin & anatomy & lombaire & & \\
\hline
\end{tabular}




\begin{tabular}{|c|c|c|c|c|}
\hline malady & general & maladie & & \\
\hline malaise & general & & & \\
\hline mallet & surgery & maillet & - & \\
\hline maniac / manic & psychiatry & maniaque & & \\
\hline massage & physiotherapy & & & \\
\hline medicine & general & $\begin{array}{l}\text { médecine / } \\
\text { médicament }\end{array}$ & & \\
\hline medicine cabinet & general & $\begin{array}{l}\text { armoire à } \\
\text { pharmacie }\end{array}$ & & \\
\hline medicochirurgical & general & $\begin{array}{l}\text { médico- } \\
\text { chirurgical }\end{array}$ & & \\
\hline migraine & neurology & & & \\
\hline morgue & general & & & \\
\hline muscle & anatomy & & & \\
\hline murmur & cardiology & souffle & & \\
\hline nerve & anatomy & nerf & & \\
\hline ointment & pharmacology & pommade & & \\
\hline oxygen & chemistry & oxygène & & \\
\hline palsy & neurology & paralysie & & \\
\hline plaster of Paris & surgery & plâtre & & \\
\hline passage & general & & & \\
\hline paste & pharmacology & pâte & & \\
\hline pastille & pharmacology & & & \\
\hline peau d'orange & dermatology & & & \\
\hline pellet & pharmacology & & & \\
\hline perle & pharmacology & & & \\
\hline perleche & dermatology & perlèche & & \\
\hline personnel & general & & & \\
\hline
\end{tabular}




\begin{tabular}{|c|c|c|c|c|}
\hline pessary & pharmacology & pessaire & & \\
\hline petit mal & psychiatry & & & \\
\hline petrissage & physiotherapy & pétrissage & & \\
\hline pharmacy & general & pharmacie & & \\
\hline physician & general & médecin & & \\
\hline physique & general & & & \\
\hline pill & pharmacology & pilule & & \\
\hline pinzette & surgery & pincette & & \\
\hline pipette & surgery & & & \\
\hline plaque & cardiology & & & \\
\hline pleurisy & pulmonology & pleurésie & & \\
\hline plombage & surgery & & & \\
\hline poison & pharmacology & & & \\
\hline polyp & dermatology & polype & & \\
\hline polypharmacy & pharmacology & polypharmacie & & \\
\hline pomade & pharmacology & pommade & & \\
\hline pore & dermatology & & & \\
\hline pouch & anatomy & poche & & \\
\hline powder & pharmacology & poudre & & \\
\hline profound & general & profond & & \\
\hline pustule & dermatology & & & \\
\hline rage & general & & & \\
\hline rale & cardiology & râle & & \\
\hline rapport & psychiatry & & & \\
\hline reservoir & virology & réservoir & & \\
\hline retard & general & & & \\
\hline rongeur & surgery & & & \\
\hline
\end{tabular}




\begin{tabular}{|c|c|c|c|c|}
\hline rouleau & haematology & & & \\
\hline sac & anatomy & & & \\
\hline sadism & psychiatry & sadisme & & \\
\hline scissors & surgery & ciseaux & & \\
\hline somnolent & neurology & & & \\
\hline souffle & cardiology & & & \\
\hline spleen & anatomy & rate & & \\
\hline stethoscope & general & stéthoscope & & \\
\hline stomach & anatomy & estomac & & \\
\hline surgeon & surgery & chirurgien & & \\
\hline talc & pharmacology & & & \\
\hline tampon & surgery & & & \\
\hline tamponade & cardiology & tamponnade & & \\
\hline tic & psychiatry & & & \\
\hline tic douloureux & neurology & & & \\
\hline torsades de pointes & cardiology & & & \\
\hline tourniquet & surgery & & turnstile & un garrot \\
\hline trepanning/trephining & surgery & trépanation & & \\
\hline trephine & surgery & trépan & & \\
\hline trocar & surgery & trocart & & \\
\hline trouble & general & & & \\
\hline trunk & anatomy & tronc & & \\
\hline tulle gras & surgery & & & \\
\hline ulcer & dermatology & ulcère & & \\
\hline urinal & general & & & \\
\hline vial & pharmacology & fiole & & \\
\hline voyeurism & psychiatry & voyeurisme & & \\
\hline
\end{tabular}


Table 2. French people whose names are associated with one or more medical terms in modern English

\begin{tabular}{|c|c|}
\hline $\begin{array}{l}\text { Neurology } \\
\text { Psychiatry }\end{array}$ & $\begin{array}{l}\text { Alajouanine, Baillarger, Barré, Bourneville, Bravais, Briquet, (Paul) Broca, } \\
\text { Brown-Séquard, Brunhes, Capgras, Cestan, Charcot, Chavany, Chenais, } \\
\text { Cornil, Cotard, Crouzon, Cruchet, de Clérambault, Dejerine, Dejerine- } \\
\text { Klumpk, Dravet, Duchenne, Duclos, Falret, Feil, Foix, Foville, Garcin, } \\
\text { Gastaut, Gilles de la Tourette, Grasset, Guillain, Hozay, Janet, Joffroy, } \\
\text { Klippel, Landouzy, Landry de Thézillat, , Léri, Lévy, Lhermitte, Londe, } \\
\text { Morel, Raymond, Sicard, Sottas, Souques, Strohl, Thaon, Thévenard, Thiers, } \\
\text { Thomas, Tinel, Trénaunay, Verger, Villaret, Vulpian, Weil }\end{array}$ \\
\hline Surgery & $\begin{array}{l}\text { Amussat, Trélat, Béclard, Béraud, Bitôt, Breschet, (Auguste) Broca, Calot, } \\
\text { Calvé, Carrel, Cathelin, Chaput, Chassaignac, Chopart, Cloquet, Delbet, } \\
\text { Delorme, Delpech, Demons, Denonvilliers, Dupuytren, Fontaine, Guyon, } \\
\text { Hartmann, Jaboulay, de La Peyronie, Labbé, Larrey, (René) Le Fort, (Léon) Le } \\
\text { Fort, Lembert, Leriche, Lisfranc, Louis, Lucas-Championnière, Malgaigne, } \\
\text { Morand, Mondor, Nélaton, Ollier, Petit, Poncet, Reclus, Robineau, Segond, } \\
\text { Tillaux }\end{array}$ \\
\hline Dermatology & $\begin{array}{l}\text { Alibert, Bazex, Besnier, Blum, Danlos, Darier, Degos, Devergie, Dubreuilh, } \\
\text { Dupré, Favre, Fournier, Gaucher, Gougerot, Hallopeau, Jacquet, Lutzner, } \\
\text { Papillon, Pautrier, Racouchot, Sabouraud, Sézary, Touraine, Wickham, } \\
\text { Woringer }\end{array}$ \\
\hline Ophthalmology & $\begin{array}{l}\text { Abadie, Amalric, Anel, Badal, Bailliart, Beauvieux, Daviel, Galezowski, Gayet, } \\
\text { Javal, Parinaud, Rochon-Duvigneaud, Sauvineau, (Georges) Weill }\end{array}$ \\
\hline Paediatrics & $\begin{array}{l}\text { Aicardi, Alagille, Apert, Bergeron, Debré, Desbuquois, Lejeune, Marfan, } \\
\text { Marie, Maroteaux, Semélaigne, (Jean) Weill }\end{array}$ \\
\hline Anatomy & $\begin{array}{l}\text { Bertin, Descemet, Donné, Littré, Magendie, Poupart, Ranvier, Sappey, } \\
\text { Vieussens }\end{array}$ \\
\hline Internal medicine & $\begin{array}{l}\text { Achard, Bard, Bouillaud, Bouveret, Carteaud, Forestier, Lasègue, Mamou, } \\
\text { Roger }\end{array}$ \\
\hline ENT & Balme, Collet, Cruveilhier, Dieulafoy, Hanot, Lermoyez, Ménière, Vincent \\
\hline Bacteriology & Calmette, Guérin, Giard, Lemierre, Pasteur, Widal, Yersin, Malassez \\
\hline Pathology & Bouchard, Brissaud, Lannelongue, Masson, Ménétrier, Trousseau \\
\hline Cardiology & Beau, Fallot, Laubry, Lenègre, Lutembacher, Vaquez \\
\hline $\begin{array}{l}\text { Gynaecology } \\
\text { Obstetrics }\end{array}$ & Auvard, Baudelocque, Levret, Mauriceau, Pozzi, Sigault \\
\hline Haematology & Abrami, Auberger, (Jean) Bernard, Hayem, Soulier \\
\hline Immunology & Arthus \\
\hline
\end{tabular}




\begin{tabular}{|l|l|}
\hline $\begin{array}{l}\text { Nephrology/ } \\
\text { Urology }\end{array}$ & Berger, Mercier \\
\hline Physiology & (Claude) Bernard, Pachon \\
\hline Dentistry & Papillon-Léage, Psaume, Robin \\
\hline Hepatology & Gilbert, Laënnec \\
\hline Gastroenterology & Caroli, Dance \\
\hline Pharmacology & Ambard \\
\hline Genetics & Lamy, Balbiani \\
\hline Phlebology & Raynaud \\
\hline Psychology & Binet \\
\hline Forensic medicine & Tardieu \\
\hline
\end{tabular}

\section{NOTES}

1. The two words in the title are meant to illustrate the course of human life (from its beginning to its end) thereby highlighting the role played by French in the English medical lexicon.

2. The word lunetie is reported by cnrtl as synonymous for 'madness' and is mentioned in the Anglo-Norman dictionary.

3. Demency (1520s) is an Anglicised version of the French démence but was replaced by the Latin form dementia in the $19^{\text {th }}$ century.

4. The first attested use of pharmacy (= drugstore) goes back to 1833.

5. The word was introduced mid-14c from Old French apotecaire 'apothecary'.

6. As most remedies were extracted from plants, they could be bought from grocers.

7. A word that designates 'a sugar-coated tablet or pill' in modern English.

8. Grand mal would translate into 'big illness' and petit mal into 'small illness'.

9. Diagnostic and Statistical Manual of Mental Disorders, $4^{\text {th }}$ edition.

10. Source: www.cnrtl.fr

11. A medicinal preparation in the form of a sticky paste or salve, usually applied to the skin on a piece of linen or leather.

12. A separate guild of master surgeons that had existed since the $14^{\text {th }}$ century and to which Ambroise Paré had belonged.

13. Source: Online Etymology Dictionary@ 2010 Douglas Harper.

14. Peau already means 'skin' in French.

15. For a comprehensive list, see Stedman's by Bartolucci \& Forbis [2005].

16. The accent has been lost.

17. In the medical literature, the term is also found without the hyphens ("cri du chat syndrome"). 


\section{ABSTRACTS}

This paper is a lexicological analysis of words imported from French into the modern English language of medicine. We replace the different contributions of the French language in their historical perspective. We endeavour to give a description of the origin of the words that entered the English language during two periods of time: that following the Norman conquest of England, illustrated by the entry of words such as malady, leprous, or palsy; and that between the 18th and the 19th centuries, marked by contributions in specialties dominated by the French such as obstetrics and gynaecology (accouchement, effacement, curettage, etc.), clinical medicine (bruit, rale, souffle, etc.), neuro-psychiatry (petit mal/grand mal, cri-du-chat, folie à deux, etc.), and surgery (bougie, curette, etc.). Because eponyms are a prominent part of the medical lexicon, and many French physicians have left their marks on the modern English medical language (Duchenne's muscular dystrophy, Descemet's membrane, Lembert's suture, etc.), we examine them separately. Our objective is to show that English has not always been pre-eminent in the language of medicine

Cette contribution est une étude lexicologique de la terminologie d'origine française dans la langue anglaise actuelle de la médecine. Nous replaçons les différents apports du français dans une perspective historique. Nous nous attachons à décrire l'origine des mots apparus lors de deux grandes vagues : celle qui suit la conquête normande de Guillaume le Conquérant, illustrée par l'entrée de mots tels que malady, leprous, ou encore palsy; et celle située entre la fin du XVIIIème et le début du XIXème siècle et marquée par les apports dans des spécialités dominées par les Français telles que la gynécologie-obstétrique (accouchement, effacement, curettage, etc.), la médecine clinique (bruit, rale, souffle, etc.), la neuropsychiatrie (petit mal/grand mal, cri-du-chat, folie à deux, etc.), et la chirurgie (bougie, curette, etc.). Parce que les éponymes représentent une part importante du lexique médical, et que nombre de médecins français ont laissé leur empreinte sur la langue médicale anglaise moderne (Duchenne's muscular dystrophy, Descemet's membrane, Lembert's suture, etc.), nous les traitons de manière séparée. Notre objectif est de montrer que l'anglais n'a pas toujours dominé le langage médical.

\section{INDEX}

Keywords: medical French, medical English, loanwords, eponyms, history of medicine Mots-clés: français médical, anglais médical, emprunts, éponymes, histoire de la médecine

\section{AUTHOR}

\section{PASCALINE FAURE}

Centre de Linguistique en Sorbonne (CeLiSo - EA 7332) Sorbonne University Pierre and Marie Curie School of Medicine

pascalinefaure@orange.fr 